\title{
小行星35633和135356的历表研制及密近交会前后 的轨道演化
}

\author{
李凡1,2*，袁烨 $1,3 ，$ 傅燕宁 ${ }^{1,3}$ \\ 1. 中国科学院紫金山天文台, 南京 210033; \\ 2. 中国科学院大学, 北京 100049 ; \\ 3. 中国科学技术大学天文与空间科学学院, 合肥 230026 \\ *联系人, E-mail: lifan@pmo.ac.cn
}

收稿日期: 2020-03-19; 接受日期: 2020-06-17; 网络出版日期: 2020-11-23

国家自然科学基金(编号: 11273066, 11178006, 11533004)和中国科学院战略性先导科技专项(编号: XDB41000000)资助项目

摘要 在已知(349)Dembowska高精度质量的情况下, 通过考虑密近交会改进了小行星35633和135356的历 表. 本文由蒙特卡罗方法给出了改进历表的不确定度, 并利用姚安高精度望远镜的观测数据验证了历表改 进的可靠性. 与未考虑密近交会因素的JPL历表比较的结果表明, 两种轨道之间瞬时根数的差值在密近交会 时刻附近快速变化, 这体现了(349)Dembowska在交会中对天体轨道演化的影响. 尽管这种影响在一定时间 内并不会产生显著的观测效应, 但在历表研制中不予以考虑会显著降低外推历表位置的精度。

关键词历表, 小行星, 密近交会

PACS: 95.10.-a, 95.10.Eg, 95.10.Km, 95.10.Jk

\section{1 引言}

小行星历表给出小行星一定时段内任意时刻 的位置和速度. 这种历表有多方面的应用价值, 比 如 $\mathrm{MPC}^{1)}$ 和JPL ${ }^{2}$ 等机构提供的历表常用来安排小行 星观测计划, 交叉证认巡天图像数据中的太阳系天 体(Miriade, Canada SSO) ${ }^{[1,2]}$, 找回丢失的小行星 ${ }^{[3]}$. 但这些历表的精度并不总能满足深空探测任务设 计 ${ }^{[4]}$ 、近地小行星撞击地球的风险评估 ${ }^{[5]}$ 、掩星事
件的预报与观测等应用的要求 ${ }^{[6]}$.

研制小行星历表需要选择恰当的动力学模型. JPL HORIZONS历表系统(以下简称JPL历表)使用 的模型SB431-N16考虑了作为质点的八大行星、冥 王星与主带 16 个较大质量的小行星. 因为在当前 观测精度下该模型并不总是足够完备, 所以JPL采 用了通过不断观测修正的策略以确保所提供历 表的精度. 显然, 这种策略并不适用于深空探测 等需要未来 5 年甚至更长时间的高精度历表的需

1) https://minorplanetcenter.net/

2) https://ssd.jpl.nasa.gov/horizons.cgi

引用格式: 李凡, 袁烨, 傅燕宁. 小行星35633和135356的历表研制及密近交会前后的轨道演化. 中国科学: 物理学 力学 天文学, 2021, 51: 029502 Li F, Yuan Y, Fu Y N. Ephemeris development for asteroids 35633 and 135356 and their orbital evolution induced by a close encounter (in Chinese). Sci Sin-Phys Mech Astron, 2021, 51: 029502, doi: 10.1360/SSPMA-2020-0080 
求. 为了满足这种需求, 在模型中不加甄别地大量 增加动力学因素并不是一个高效实用的方法. 本 文在定量分析各种可能对小行星35633和135356产 生显著影响的动力学因素的基础上, 发现在有关 动力学模型中应该增加与它们分别有密近交会 的(349)Dembowska的引力作用, 由此得到的历表在 外推精度上有明显改进(下文中称考虑了密近交会 影响的历表为改进历表). 其中本文中密近交会事件 的标准来自 Tang等人 ${ }^{[7]}$ 的笁选工作, 即该密近交会 事件能够在 5 年内产生可观测的摄动效应. 改进历表 的外推精度通过姚安高精度望远镜观测数据进行了 验证. 此外, 通过与不考虑密近交会的JPL历表瞬时 轨道根数的对比揭示了(349)Dembowska在交会中 对天体轨道演化的影响.

\section{2 动力学模型}

为了给出天体的历表, 首先需要选择恰当的动 力学模型. 主带小行星主要受太阳的引力作用, 其 他的引力或者非引力因素的取舍决定于这些因素能 否产生显著的观测效应.

JPL历表所采用的动力学模型为SB431-N16, 其 中考虑了作为质点的太阳、八大行星、冥王星及 主带16个较大质量小行星的引力, 其中太阳、八 大行星、冥王星考虑了相对论修正. 该模型的动 力学方程为(1), 其中, $\boldsymbol{r}_{i}, \dot{\boldsymbol{r}}_{i}, \ddot{\boldsymbol{r}}_{i}$ 分别是天体 $i$ 在太阳系 质心天球参考系(BCRS)中的位置、速度和加速度; $\mu_{j}=G m_{j}$, 其中 $G$ 是引力常数, $m_{j}$ 是天体 $j$ 的质量; $r_{i j}=\left|\boldsymbol{r}_{j}-\boldsymbol{r}_{i}\right| ; \gamma, \beta$ 是参数化后牛顿参数, 它们的取 值都为 $1 ; v_{i}=\left|\dot{\boldsymbol{r}}_{i}\right| ; c$ 是光速; 时间尺度为质心力学 时(TDB):

$$
\begin{aligned}
\ddot{\boldsymbol{r}}= & \sum_{j \neq i} \frac{\mu_{j}\left(\boldsymbol{r}_{j}-\boldsymbol{r}_{i}\right)}{r_{i j}^{3}}\left\{1-\frac{2(\beta+\gamma)}{c^{2}} \sum_{k \neq i} \frac{\mu_{k}}{r_{i k}}\right. \\
& -\frac{2 \beta-1}{c^{2}} \sum_{k \neq j} \frac{\mu_{k}}{r_{j k}}+\gamma\left(\frac{v_{i}}{c}\right)^{2}+(1+\gamma)\left(\frac{v_{j}}{c}\right)^{2} \\
& -\frac{2(1+\gamma)}{c^{2}} \dot{\boldsymbol{r}}_{i} \cdot \dot{\boldsymbol{r}}_{j}-\frac{3}{2 c^{2}}\left[\frac{\left(\boldsymbol{r}_{i}-\boldsymbol{r}_{j}\right) \cdot \dot{\boldsymbol{r}}_{j}}{r_{i j}}\right]^{2}
\end{aligned}
$$

3) https://ssd.jpl.nasa.gov/x/spk.html

4) https://naif.jpl.nasa.gov/pub/naif/generic_kernels/spk/planets/

$$
\begin{aligned}
& \left.+\frac{1}{2 c^{2}}\left(\boldsymbol{r}_{j}-\boldsymbol{r}_{i}\right) \cdot \ddot{\boldsymbol{r}}_{j}\right\} \\
& +\frac{1}{c^{2}} \sum_{j \neq i} \frac{\mu_{j}}{r_{i j}^{3}}\left\{[ \boldsymbol { r } _ { i } - \boldsymbol { r } _ { j } ] \cdot \left[(2+2 \gamma) \dot{\boldsymbol{r}}_{i}\right.\right. \\
& \left.\left.-(1+2 \gamma) \dot{\boldsymbol{r}}_{j}\right]\right\}\left(\dot{\boldsymbol{r}}_{i}-\dot{\boldsymbol{r}}_{j}\right) \\
& +\frac{3+4 \gamma}{2 c^{2}} \sum_{j \neq i} \frac{\mu_{j} \ddot{\boldsymbol{r}}_{j}}{r_{i j}}+\sum_{m=1}^{16} \frac{\mu_{m}\left(\boldsymbol{r}_{m}-\boldsymbol{r}_{i}\right)}{r_{i m}^{3}} .
\end{aligned}
$$

也有一些学者在考虑大行星质点引力基础上 还考虑太阳的形状摄动、某些大行星的形状摄动、 Yarkovsky效应、太阳光压等 ${ }^{[8-10]}$. 由于太阳光压 一般只对微米级和亚微米级颗粒有显著作用 ${ }^{[1]}$, Yarkovsky效应一般较长时间才能体现 ${ }^{[12]}$, 因此针 对本文考虑的历表天体我们重点考察三大天体(太 阳、土星、木星)的形状摄动以及密近交会效应.

以SB431-N16为基础, 从对35633产生的加速度 与观测效应两方面分析了(349)Dembowska及太阳、 木星、土星J2项的影响. 其中(349)Dembowska的 $\mathrm{GM}$ 为 $(0.274909 \pm 0.0267) \mathrm{km}^{3} / \mathrm{s}^{2}[13], \mathrm{SB} 431-\mathrm{N} 16$ 模型 中 16 个大质量小行星GM见表 1. 16个大质量小行 星与(349)Dembowska位置均来自JPL历表 ${ }^{3)}{ }^{[14]}$. 大 行星位置、质量及其他参数值来源于DE4314) [15]. 表2给出了35633与(349)Dembo-wska密近交会的 相关信息, 其中 $t_{\mathrm{enc}}$ 表示交会时刻, $t_{0}$ 表示拟合 时选定的初始时刻, 最小距离表示密近交会 时(349)Dembowska与历表天体的距离. 根据Tang等 人 ${ }^{[7]}$ 给出的密近交会信息, (349)Dembowska与两小 行星在观测时段内分别仅有一次密近交会.

图 1给出了35633在1990-2030年间太阳J2项、 木星J2项、 (349)Dembowska产生的加速度分别 与(1)Ceres产生的加速度的比值. 结果表明各J2项 带来的加速度最大仅为(1)Ceres产生的加速度 的 11\%(土星J2项更低), 而(349)Dembowska带来的加 速度则在密近交会附近超过了(1)Ceres所引起的加 速度.

图 2(a)和(b)显示了SB431-N16分别与SB431N16加上太阳、木星J2、SB431-N16加上(349)Dem- 
表 116 个大质量小行星GM值

Table 1 The GM of 16 massive asteroids

\begin{tabular}{ccc}
\hline 小行星编号 & 名称 & $\mathrm{GM}\left(\mathrm{km}^{3} / \mathrm{s}^{2}\right)$ \\
\hline 1 & Ceres & $6.2809393000000000 \times 10^{1}$ \\
2 & Pallas & $1.3923011000000001 \times 10^{1}$ \\
3 & Juno & $1.6224149999999999 \times 10^{0}$ \\
4 & Vest & $1.7288008999999999 \times 10^{1}$ \\
10 & Hygiea & $5.5423920000000004 \times 10^{0}$ \\
15 & Eunomia & $2.0981550000000002 \times 10^{0}$ \\
16 & Psyche & $1.5300480000000001 \times 10^{0}$ \\
31 & Euphrosyne & $2.8448720000000001 \times 10^{0}$ \\
48 & Doris & $1.1351590000000000 \times 10^{0}$ \\
52 & Europa & $1.1108039999999999 \times 10^{0}$ \\
65 & Cybele & $1.4264810000000001 \times 10^{0}$ \\
87 & Sylvia & $9.8635300000000004 \times 10^{-1}$ \\
88 & Thisbe & $1.1557990000000000 \times 10^{0}$ \\
451 & Patientia & $1.0295259999999999 \times 10^{0}$ \\
511 & Davida & $2.3312860000000000 \times 10^{0}$ \\
704 & Interamnia & $2.3573170000000001 \times 10^{0}$ \\
\hline
\end{tabular}

表 2 历表天体35633和135356与(349)Dembowska密近交会 信息

Table 2 Close encounters between (349)Dembowska and the two ephemeris bodies, 35633 and 135356, respectively

\begin{tabular}{cccc}
\hline 历表天体 & $t_{\text {enc }}$ & 最小距离 $(\mathrm{AU})$ & $t_{0}(\mathrm{TDB})$ \\
\hline 35633 & $2016-08-08$ & 0.0035 & $2017-02-18$ \\
135356 & $2008-04-23$ & 0.0012 & $2007-09-15$ \\
\hline
\end{tabular}

bowska对35633积分的历表位置之差 $\Delta C$ 随时间的变 化, 其中 $\Delta C_{\mathrm{d}}$ 表示空间距离之差, $\Delta C_{\mathrm{a}}$ 表示地心角距 离之差. 从中可以看出, 在 30 年间, 两大天体 $\mathrm{J} 2$ 项 引起的 $\Delta C_{\mathrm{d}}$ 最大为 $0.15 \mathrm{~km}, \Delta C_{\mathrm{a}}$ 最大为 $0.0001 \mathrm{arcsec}$. 而SB431-N16与SB431-N16加(349) Dembowska模型 之差则达到了 $1000 \mathrm{~km}(0.8 \mathrm{arcsec})$, 可以被当前地 面的常规望远镜分辨. 对135356也有类似的分析 结果. 据上述分析可知, 对于本文所讨论的两个历 表天体而言, 其动力学模型考虑SB431-N16模型加 上(349)Dembowska的引力是恰当的.

\section{3 观测资料、拟合与不确定度估计}

历表研制中参与轨道拟合的观测资料均来 自AstDyS ${ }^{5)}{ }^{[16]}$ 网站6). 表 3给出了历表天体观测资料 的数量、时间跨度等. 图 3给出了观测资料的时间 分布. 观测资料改正了处理过程中使用参考星表所

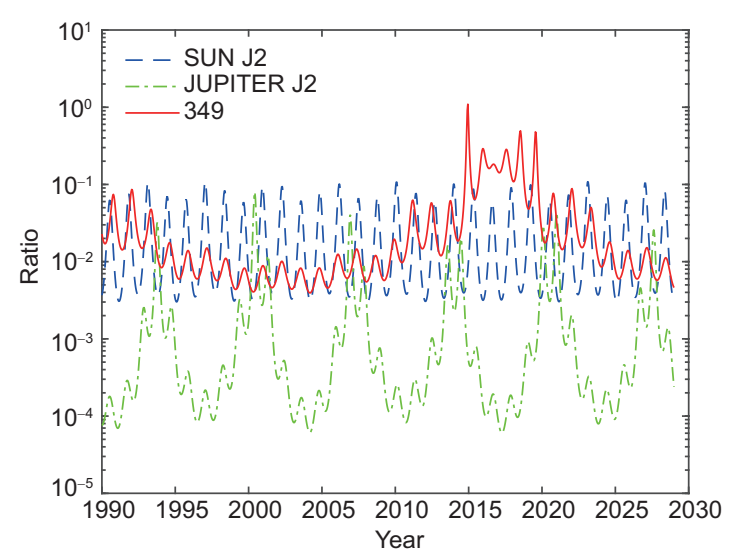

图 1 (网络版彩图)不同摄动因素分别与(1)Ceres分别引 起35633的加速度之比, 其中摄动因素为太阳J2项和木 星J2项时最大仅为 0.11 , 而为(349)Dembowska时最大可超 过 1

Figure 1 (Color online) The ratio of the acceleration of 35633 from various factors to that from (1)Ceres. The values for J2 of the Sun and of Jupiter are below about 0.11, while the value from (349)Dembowska can be greater than 1 .

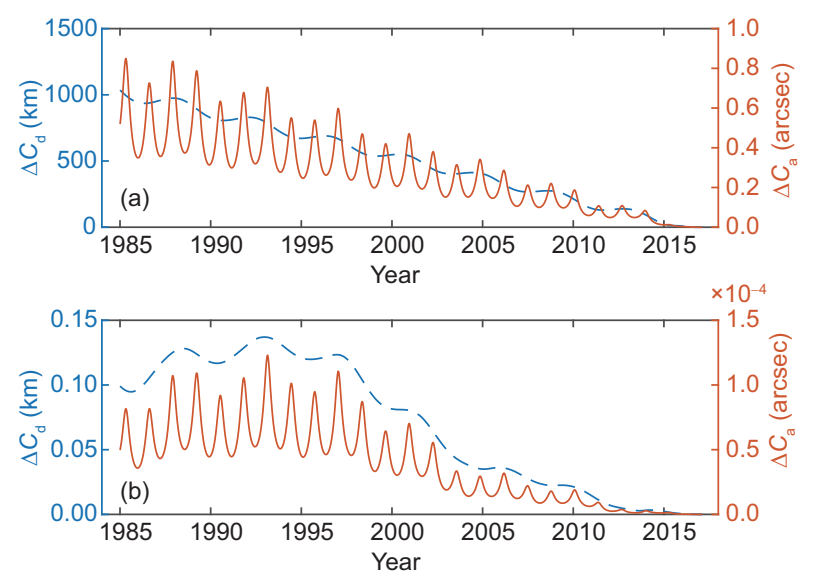

图 2 (网络版彩图) (a) 考虑(349)Dembowska导致的 $\Delta C_{\mathrm{d}}$ 和 $\Delta C_{\mathrm{a}}$, 其中 $\Delta C_{\mathrm{d}}$ 和 $\Delta C_{\mathrm{a}}$ 分别为两历表空间距离和从地心 看过去角距离之差. $\Delta C$ 最大值约为 $1000 \mathrm{~km}(0.8 \mathrm{arcsec})$. (b) 考虑太阳、木星 $\mathrm{J} 2$ 导致的 $\Delta C_{\mathrm{d}}$ 和 $\Delta C_{\mathrm{a}}$, 其中最大约为 $0.15 \mathrm{~km}$ (0.0001 arcsec)

Figure 2 (Color online) (a) $\Delta C_{\mathrm{d}}$ and $\Delta C_{\mathrm{a}}$ of model SB431-N16 with respect to SB431-N16 plus (349)Dembowska, where $\Delta C_{\mathrm{d}}$ and $\Delta C_{\mathrm{a}}$ are the differences of the two ephemerides expressed respectively, as linear distance in physical space and angular distance seen from the Earth center. The maximum of $\Delta C$ is $1000 \mathrm{~km}(0.8 \mathrm{arcsec})$. (b) $\Delta C_{\mathrm{d}}$ and $\Delta C_{\mathrm{a}}$ of model SB431-N16 with respect to SB431-N16 plus J2 of two objects (the Sun, Jupiter). The maximum of $\Delta C$ is $0.15 \mathrm{~km}(0.0001 \mathrm{arcsec})$.

5) https://newton.spacedys.com/astdys/

6) 访问于 2019年4月 8 日, 并于访问当日从JPL HORIZONS获取历表天体的历表 
表 3 用于研制历表的历表天体观测资料

Table 3 Astrometric observations used in developing the ephemerides

\begin{tabular}{ccc}
\hline 小行星 & 时间段 (yyyy-mm) & 数量 $($ 个) \\
\hline 35633 & $(1980-01,2018-03)$ & 1215 \\
135356 & $(1992-10,2018-09)$ & 493 \\
\hline
\end{tabular}

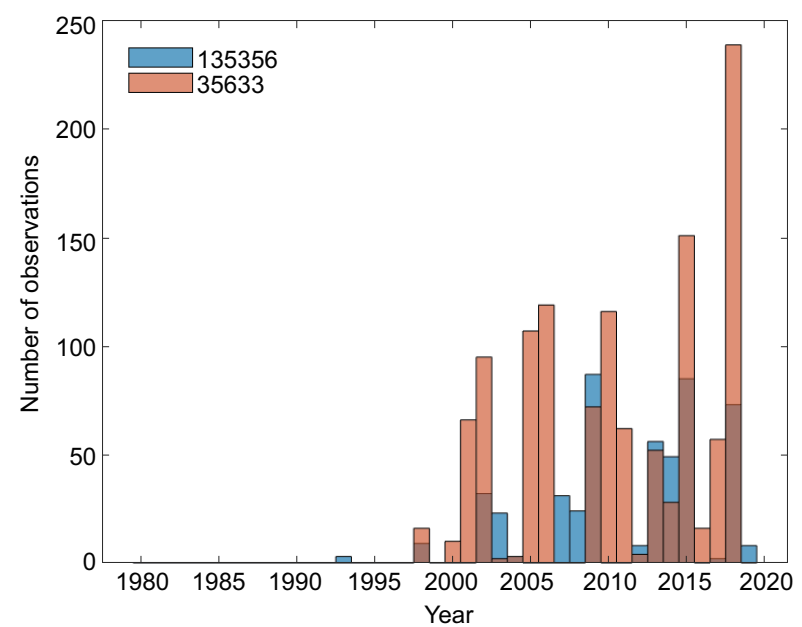

图 3 (网络版彩图)历表天体观测资料分布

Figure 3 (Color online) The distribution of observations of the objects.

带来的系统差 ${ }^{[17]}$. 通过最小二乘法拟合确定历表天 体在BCRS中的初始条件 $\boldsymbol{x}$. 目标函数为

$\chi^{2}=\sum_{i=1}^{n}\left(\frac{O_{i}-C\left(t_{i}, \boldsymbol{x}\right)}{\sigma_{i}}\right)^{2}$

其中 $\boldsymbol{x}$ 作为模型参数, $O_{i}$ 与 $C\left(t_{i}, \boldsymbol{x}\right)$ 分别为观测量 在 $t_{i}$ 时刻的观测值与计算值, $\sigma_{i}$ 为Farnocchia等 人 ${ }^{[17]}$ 给出的观测误差. $C$ 的计算涉及对方程(1)的 积分, 其中最后一项包括了(349)Dembowska的引力. 积分方法使用变阶变步长Admas算法 ${ }^{[18]}$, 改进历表 采用IAU历表委员会推荐的SPK格式 ${ }^{[19]}$ 在线发布 ${ }^{7)}$, 其中插值精度好于 $5 \mathrm{~cm}$.

历表位置的不确定度使用蒙特卡罗方法给 出 ${ }^{[20]}$, 其基本思想是根据观测误差生成观测值的若 干不同样本, 由不同样本出发得到的拟合参数值视 为这些参数的不同取样. 由拟合参数的不同取样可 以计算得到不同的历表取样, 我们用这些取样的弥 散估计历表的不确定度. 对于第 $k$ 次拟合得到的历 表, 记 $d_{k}(t)$ 为 $t$ 时刻该历表与原始观测资料给出的历
表位置之差, 并用 $\left(d_{k}\right)_{k=1, \cdots, K}$ 的标准差定量描述历表 的不确定度, 即

$\sigma_{s}(t)=\sqrt{\frac{1}{K-1} \sum_{k=1}^{K}\left(d_{k}(t)-\bar{d}(t)\right)^{2}}$,

其中 $K$ 取值为 1000 .

\section{4 改进历表及其不确定度}

\section{1 小行星 35633}

35633 是一颗于 1988 年5月22日由美国LINEAR 计划 [21]发现的主带小行星. 拟合时选择JPL历表中 的位置作为初始条件的初始猜测值进行迭代, 表 4给出了改进历表关于BCRS的瞬时轨道根数. 在得 到初始条件后, 经过数值积分得到了35633的历表. 表 5给出了改进历表与JPL历表相对于拟合资料的 偏差, 其中赤经方向残差均值 $\langle\Delta \alpha \cos \delta\rangle$ 有了较大改 善, 赤纬方向残差均值 $\langle\Delta \delta\rangle$ 略有降低, 两个方向标准 差相差不大.

图 4给出了1960-2030年改进历表与JPL历表之 间的赤经赤纬差异. 从图 4可以看出, 赤经方向差 值 $\Delta \alpha \cos \delta$ 分别在 2019,2023 和2027年分别达到局部

表 4 35633在2017-02-18(TDB)历元时刻的BCRS质心瞬时 轨道根数

Table 4 Osculating orbital elements of 35633 with respect to BCRS at epoch 2017-02-18(TDB)

\begin{tabular}{ccc}
\hline 轨道根数 & 拟合值 & 不确定度 $(1-\sigma)$ \\
\hline 半长径 $(\mathrm{au})$ & 2.5201152236 & $4.773275 \times 10^{-8}$ \\
偏心率 & 0.0487634522 & $1.849314 \times 10^{-8}$ \\
轨道倾角 $(\mathrm{rad})$ & 0.4822262948 & $5.071048 \times 10^{-8}$ \\
升交点经度 $(\mathrm{rad})$ & 0.2961984690 & $9.706329 \times 10^{-8}$ \\
近心点角距 $(\mathrm{rad})$ & 2.0728061264 & $6.309929 \times 10^{-7}$ \\
平近点角 $(\mathrm{rad})$ & 4.0048967516 & $6.206549 \times 10^{-7}$ \\
\hline
\end{tabular}

表 5 35633改进历表与JPL历表的残差均值与标准差

Table 5 Mean and standard deviation of residuals for 35633 by using ephemerides from this paper and JPL

\begin{tabular}{ccccc}
\hline 历表 & $\langle\Delta \alpha \cos \delta\rangle$ & $\mathrm{SD}_{\alpha \cos \delta}$ & $\langle\Delta \delta\rangle$ & $\mathrm{SD}_{\delta}$ \\
\hline JPL & -0.07 & 0.52 & 0.08 & 0.46 \\
改进 & 0.02 & 0.51 & 0.10 & 0.46 \\
\hline
\end{tabular}

7) http://paperdata.china-vo.org/Li.Fan/ephemerides/ephemerides.zip 


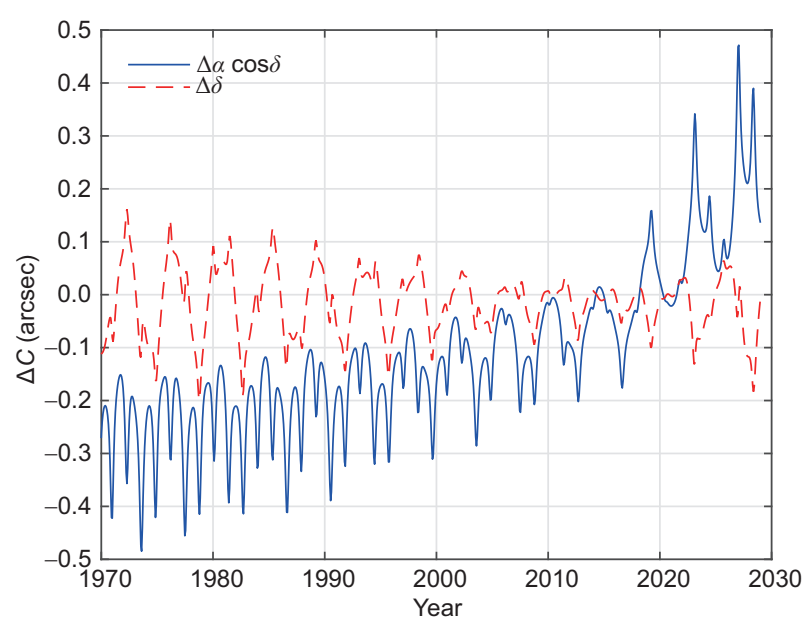

图 4 (网络版彩图)35633改进历表与JPL历表赤经赤纬差 异. 其中 $\Delta \alpha \cos \delta$ 分别在 2019,2023 和2027年达到局部极大 值 $0.16,0.34,0.47 \mathrm{arcsec}$, 可以被当前地面观测设备分辨

Figure 4 (Color online) Difference between ephemerides of 35633 from this paper and JPL in right ascension and declination. $\Delta \alpha \cos \delta$ come up to local maxima of $0.16,0.34,0.47 \mathrm{arcsec}$ in the year of 2019, 2023 and 2027. This difference can be detectable with ground based telescope.

极大值 $0.16,0.34,0.47 \mathrm{arcsec}$, 可以被当前地面观测 设备分辨. 该差异的主要原因为两历表动力学模 型不一样, 即是否考虑与(349)Dembowska密近交会. 两历表在观测数据拟合时间段相差不大, 而在外推 后差异较大. 这是由于在模型不完备时, 依然有可能 通过拟合参数取值的调整使得在观测数据所在时间 范围得到在观测精度上符合观测的历表, 但这种取 值与真值之间的偏差将在外推上表现出来.

图 5给出了由蒙特卡罗方法得到的 $\sigma_{s}$ 随时间的 变化, 其中右 $y$ 轴 $\sigma_{\mathrm{a}}$ 表示从地心看过去 $\sigma_{s}$ 张成的角. 从图 5可以看出, 历表的不确定度在2010-2019年间 较低 $(22 \mathrm{~km})$ 并朝两端发散.

\section{2 小行星135356}

135356也是一颗由美国LINEAR计划发现的主 带小行星, 发现时间是2001年10月14日.

表 6给出了改进历表关于BCRS的瞬时轨道根 数. 表 7给出了改进历表与JPL历表相对于拟合资料 的偏差, 其中赤经、赤纬方向残差标准差略有改善,

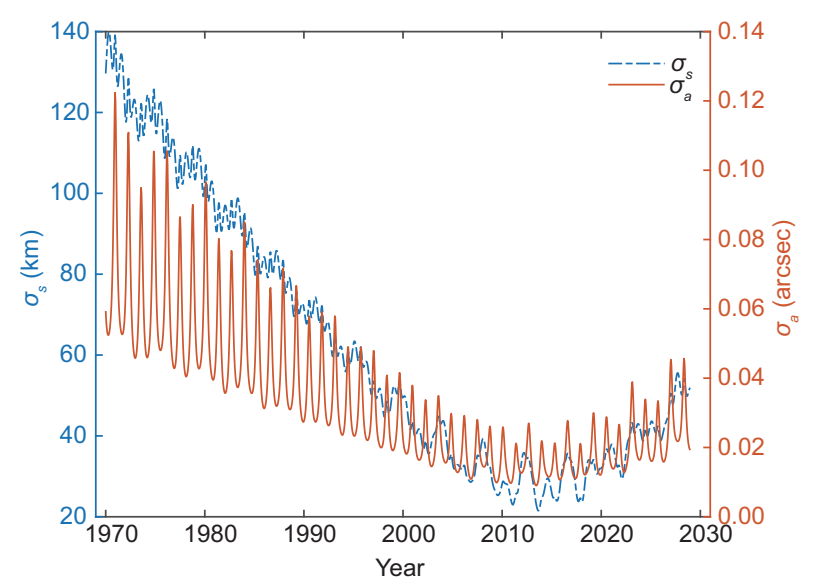

图 5 (网络版彩图)35633历表不确定度随时间的变化. 其 在2010-2019年间较低 $(22 \mathrm{~km})$ 并朝两端发散

Figure 5 (Color online) The uncertainty of ephemeris of 35633 change with time. The uncertainty maintains a low value of $22 \mathrm{~km}$ in 2010-2019 and diverges in both directions.

表 6 135356在2008-11-01(TDB)历元时刻的轨道根数

Table 6 Osculating orbital elements of 135356 with respect to BCRS at epoch 2008-11-01(TDB)

\begin{tabular}{ccc}
\hline 轨道根数 & 拟合值 & 不确定度 $(1-\sigma)$ \\
\hline 半长径 $(\mathrm{au})$ & 2.8520422712 & $9.982895 \times 10^{-8}$ \\
偏心率 & 0.0818551199 & $3.082607 \times 10^{-8}$ \\
轨道倾角 $(\mathrm{rad})$ & 0.5554948322 & $9.761788 \times 10^{-8}$ \\
升交点经度 $(\mathrm{rad})$ & 6.1818068981 & $1.101773 \times 10^{-7}$ \\
近心点角距 $(\mathrm{rad})$ & 1.4799998506 & $6.707987 \times 10^{-7}$ \\
平近点角 $(\mathrm{rad})$ & 0.8966909568 & $6.354616 \times 10^{-7}$ \\
\hline
\end{tabular}

表 7 135356改进历表与JPL历表与历史观测资料统计对比

Table 7 Statistics of residuals for 135356 by using ephemerides from this paper and JPL

\begin{tabular}{ccccc}
\hline 历表 & $\langle\Delta \alpha \cos \delta\rangle$ & $\mathrm{SD}_{\alpha \cos \delta}$ & $\langle\Delta \delta\rangle$ & $\mathrm{SD}_{\delta}$ \\
\hline JPL & -0.04 & 0.51 & 0.09 & 0.44 \\
改进 & 0.03 & 0.50 & 0.10 & 0.44 \\
\hline
\end{tabular}

残差均值则差异不大.

图 6给出了改进历表与JPL历表在1960-2030年 的赤经赤纬差异. 从图 6可以看出, 改进历表 与JPL历表差异从2008年开始沿着时间轴反向增大, 而在2010-2030年间两者差异则较小 $(<0.08$ arcsec).

图 7给出了通过蒙特卡罗方法得到的 $\sigma_{s}$ 随时间 的变化, 其中右 $y$ 轴 $\sigma_{\mathrm{a}}$ 表示从地心上看过去 $\sigma_{s}$ 所张成 的角. 从图 7可以看出, 历表的不确定度在 2013 年最 低 $(29 \mathrm{~km})$ 并朝两端缓慢发散. 


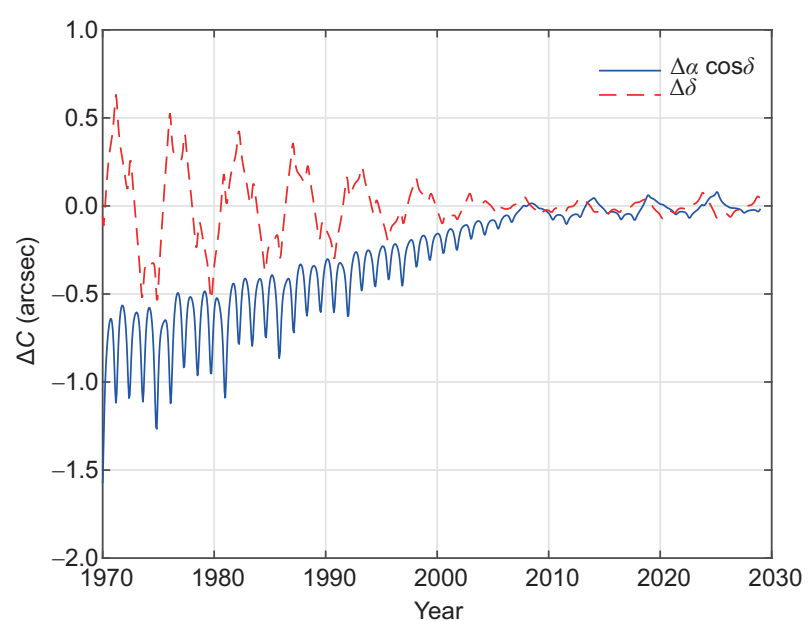

图 6 (网络版彩图)135356改进历表与JPL历表赤经赤纬差 异. 差异从2008年开始向过去方向逐渐变大. 这可以用于从 历史资料中提取观测资料

Figure 6 (Color online) Difference between ephemeris of 135356 from this paper and JPL in both right ascension and declination. The difference increases with the time goes back from 2008. The big difference may help to find observations from old images.

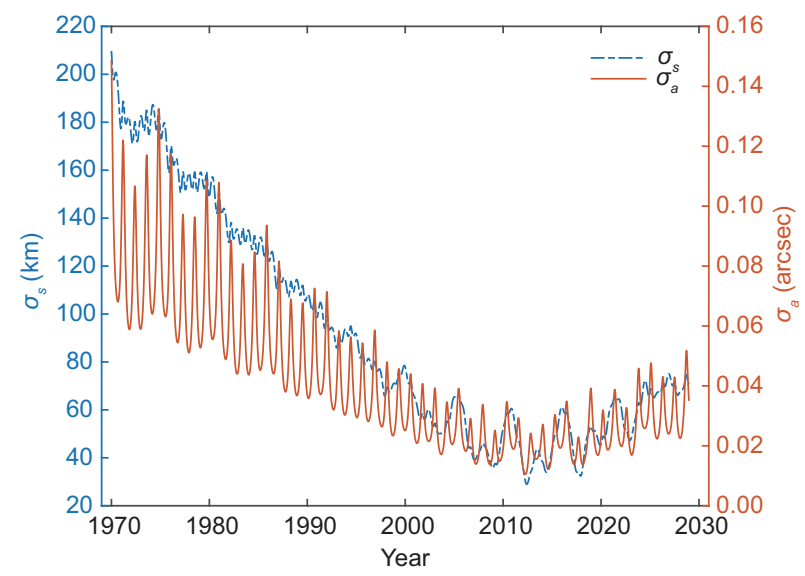

图 7 (网络版彩图)135356历表不确定度随时间的变化

Figure 7 (Color online) The time-dependent uncertainty of ephemeris of 135356 .

\section{5 讨论}

\section{1 外符合分析}

为了检验改进历表的外符合程度, 利用姚安高 精度望远镜对历表天体进行了位置观测.

从2019年1月9日持续到2019年3月30日对35633 共19晚拍摄了178幅图像, 从2019年1月3日到2019年
2月11日对135356共11晚拍摄了64幅图像. 姚安高精 度望远镜及相机的相关参数见表 8 .

观测资料处理使用MAAT ${ }^{[22]}$ 并使用Gaia DR2 ${ }^{[23]}$ 作为参考星表. 表 9给出了JPL历表与改 进历表各自的残差统计结果. 从表 9 可以看 出 35633 赤经方向残差均值 $\langle\Delta \alpha \cos \delta\rangle$ 从 0.21 改进 至 $0.06 \mathrm{arcsec}$, 赤纬方向残差均值 $\langle\Delta \delta\rangle$ 则从-0.06改 进至0.03 arcsec. 135356小行星改进历表残差均 值略优于JPL历表而标准差相当. 两小行星密近 交会发生的时刻不同, 这使得(349)Dembowska摄 动带来的影响时间段有差异. 特别地, 35633密 近交会发生在2016年8月8日，而其参与拟合历 表的观测资料最晚则在2018年3月16日，因此考 虑(349)Dembowska引力的历表往未来外推效果 显著.

\section{2 密近交会事件中影响历表精度的因素分析}

如式(2)所示, 改进后历表拟合时参数仅为 历表天体的状态, 而认为背景引力场所涉及参 数(如大行星质量及位置、(349)Dembowska质量 及位置)均为已知且准确的. 为了估计背景引力 场相关参数对所得历表精度的影响, 我们选取 了几个典型的背景引力场参数进行了计算. 首先 考察(349)Dembowska质量的影响, 即在背景引力场

表 8 姚安高精度望远镜及相机参数

Table 8 Specifications of the Yaoan High Precision Telescope and CCD detector

\begin{tabular}{cc}
\hline 参数 & 值 \\
\hline 口径 & $0.8 \mathrm{~m}$ \\
焦距 & $8 \mathrm{~m}$ \\
视场大小 & $11 \operatorname{arcmin} \times 11 \mathrm{arcmin}$ \\
像元比例尺 & $0.346 \operatorname{arcsec} /$ pixel \\
CCD像素数 & $2048 \times 2048$ \\
\hline
\end{tabular}

表 9 JPL历表与改进历表与姚安天体测量望远镜观测资料 统计对比

Table 9 Statistics of ephemerides residuals with respect to observations from Yaoan High Precision Telescope

\begin{tabular}{ccccc}
\hline 历表 & $\langle\Delta \alpha \cos \delta\rangle$ & $\mathrm{SD}_{\alpha \cos \delta}$ & $\langle\Delta \delta\rangle$ & $\mathrm{SD}_{\delta}$ \\
\hline $\mathrm{JPL}(35633)$ & 0.21 & 0.15 & -0.06 & 0.10 \\
改进(35633) & 0.06 & 0.15 & 0.03 & 0.10 \\
$\mathrm{JPL}(135356)$ & 0.09 & 0.20 & 0.09 & 0.20 \\
改进(135356) & 0.03 & 0.20 & 0.06 & 0.20 \\
\hline
\end{tabular}


中修改(349)Dembowska GM为 $0.3341 \mathrm{~km}^{3} / \mathrm{s}^{2}(1-\sigma$ 上 限), 将该模型记作MA. 其次考察(349)Dembowska位 置的影响. 通过在其轨道根数上加上由JPL HORIZONS给出的轨道根数不确定度并重新利用SB431N16进行积分得到(349)Dembowska新的历表用于 背景引力场计算, 该模型记作MB. 最后考察大行 星位置的影响. 我们选择使用INPOP13c大行星历 表 ${ }^{[24]}$ 来替换DE431并将该模型记作MC. 上述三模 型均根据观测资料重新拟合给出各自对应的历表.

图 8给出了35633与135356在不同模型(MA, $\mathrm{MB}, \mathrm{MC})$ 下所得历表与改进后历表的差值, 其 中 $\sigma_{s}$ 为历表的不确定度. 从图中可以看出, 三种情况
下所得历表与改进后历表的差值均小于历表的不确 定度. 此外, 三种模型相互比较可以看出, MA模型 产生的误差更容易达到历表不确定度. 因此在密近 交会事件中, 小行星质量精度对其历表外推精度影 响较大.

\section{3 密近交会对瞬时轨道根数的影响}

为了考察密近交会引起历表天体轨道的演化 情况, 我们计算了改进历表与JPL历表在日心黄道 坐标系下瞬时轨道根数之间的差值. 图 9给出了两 者瞬时轨道半长径 $a$, 偏心率 $e$, 轨道倾角 $i$ 的差值随
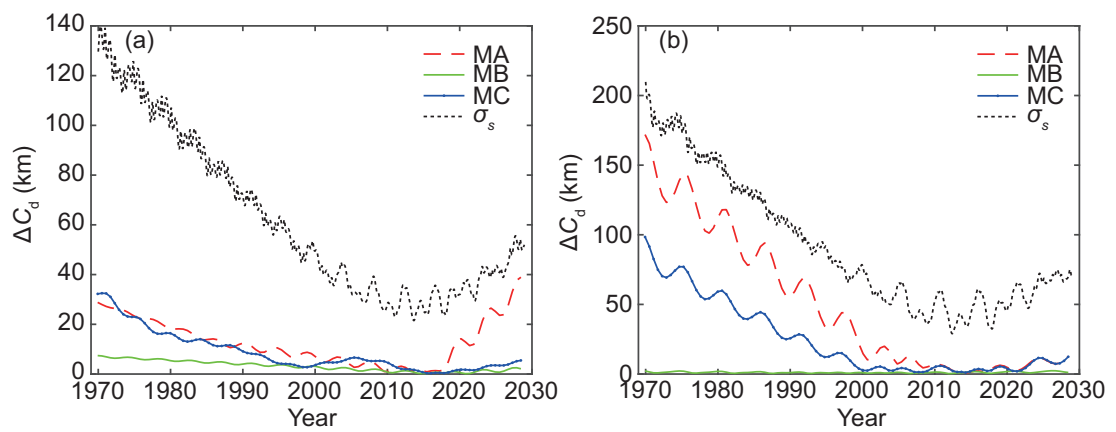

图 8 (网络版彩图) 35633 (a)与135356 (b)各自三种模型(MA, MB, MC)所得历表与改进后历表的空间距离, 其中 $\sigma_{s}$ 为改进后 历表的不确定度. 三种情况下距离均小于 $\sigma_{s}$

Figure 8 (Color online) The distance of ephemerides of 35633 (a) and 135356 (b) derived from three models (MA, MB, MC) with respect to the improved ephemeris. $\sigma_{s}$ also shows in the figure. In three cases, the distances are less than $\sigma_{s}$.
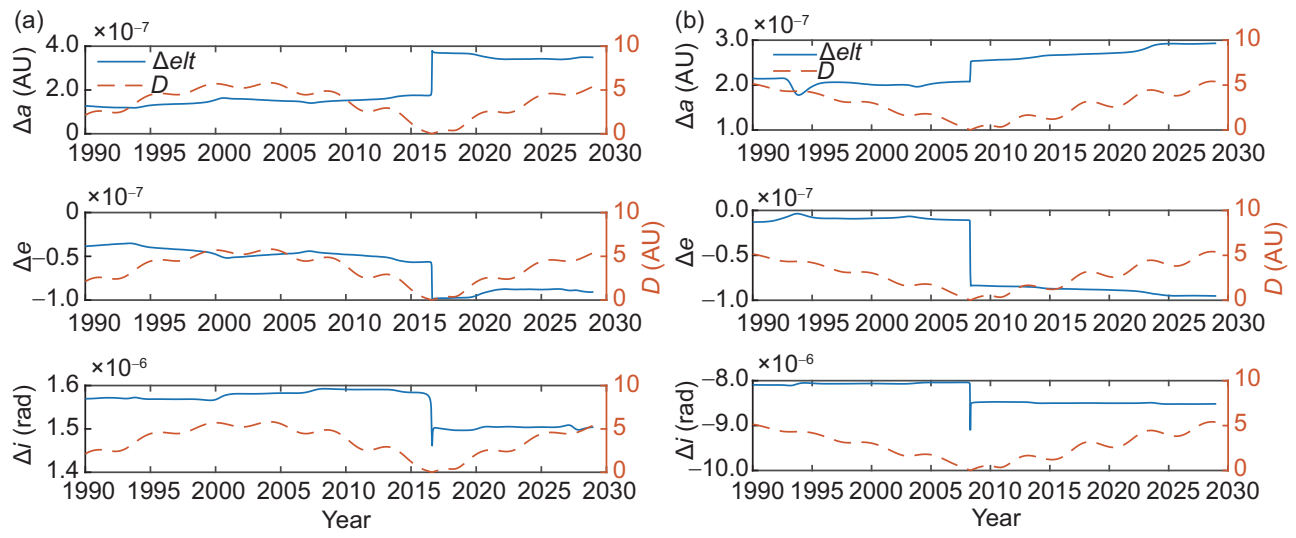

图 9 (网络版彩图) 35633 (a)与135356 (b)改进历表与JPL历表在日心黄道坐标系下瞬时轨道根数的差值. 每个子图从上到下 分别代表轨道半长径、偏心率与轨道倾角的计算结果. 容易发现在密近交会附近由于(349)Dembowska的摄动影响导致突变

Figure 9 (Color online) Differences of osculating orbital elements for 35633 (a) and 135356 (b) in heliocentric ecliptic system between ephemerides from this paper and JPL. For every subfigure, from top to bottom, the shown results are the differences in $\Delta a, \Delta e$ and $\Delta i$. It is easy to see that the differences change rapidly when targets encounter with (349)Dembowska. 
时间的演化. 从中可以看出，两个历表天体的 瞬时轨道均在密近交会时刻附近突变. 实际上, (349)Dembowska引力作用范围小, 相应的交会有 效时间段短, 因此瞬时轨道根表现出快速变化现 象. 图 10为35633突变部分放大图, 可看出瞬时轨 道的变化在 $10 \mathrm{~d}$ 左右完成. 这种瞬时轨道快速变 化的现象可作为密近交会事件的探针. 此外, 联合 瞬时轨道与角距离变化情况(图 4与图 6)可以看出, (349)Dembowska引力效果可以很快体现在瞬时轨 道根数上, 但是在三维空间中的位置差异却需要时 间才能体现. 这与 Tang等人 ${ }^{[7]}$ 认为密近交会需要一 段时间才能体现出观测效应的观点相吻合.
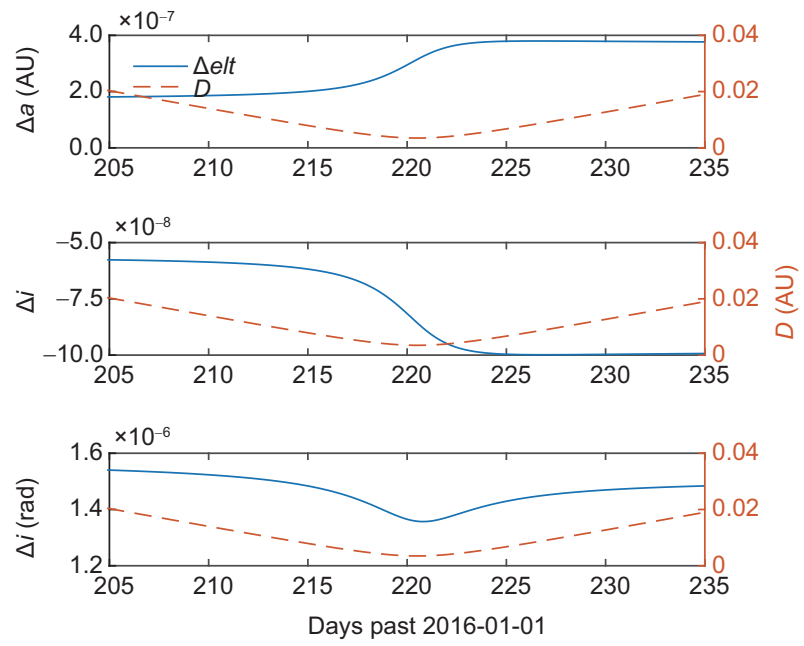

图 10 (网络版彩图)图 9(a)突变部分的放大. 可以看出 瞬时轨道根数差值的快速变化只经历了 $10 \mathrm{~d}$ 左右. 这 与(349)Dembowska的引力作用范围小有关

Figure 10 (Color online) Enlargement of Figure 图 9(a) for the part of rapidly changing. The rapidly changing lasts only about $10 \mathrm{~d}$. This is related to the small gravitational range of (349)Dembowska.

\section{6 总结}

高精度小行星历表对包括深空探测在内的 很多科学研究都具有非常重要的意义. 本文以 与(349)Dembowska有密近交会的两颗小行星为例 研制了小行星历表并讨论了密近交会前后的轨道 演化.

首先给出了考虑密近交会后两颗小行星的历 表及其依赖于时间的不确定度, 并与未考虑此因素 的JPL历表做了比较. 结果表明, 尽管在拟合模型 中计及密近交会因素对拟合的内符合精度改进有 限, 但对历表的外推精度改进显著. 这种改进的具 体表现综合依赖于观测资料相对于交会时刻的时 间与精度分布. 对于 35633 , 其观测资料主要分布于 交会之前, 改进主要表现于未来时段, 在外推 1 年后 的 2019 年可达 $0.16 \mathrm{arcsec}, 5$ 年后可达 $0.34 \mathrm{arcsec}$. 对 于135356, 其观测资料分布在密近交会时刻两侧且 观测精度逐渐提高, 综合导致其向过去外推差异 较大, 此差异可以用于搜寻早期的未被收录的观测 资料.

使用外符合分析验证了改进历表的外推精度 改进. 对于 35633 , 其赤经方向残差均值从 0.21 改进 到 $0.06 \mathrm{arcsec}$, 赤纬方向从-0.06改进至 $0.03 \mathrm{arcsec}$. 密近交会前后轨道演化表明密近交会对小行星动力 学影响表现在密近交会时刻附近瞬时轨道根数差值 的快速变化. 这种现象可作为具有显著效应的密近 交会事件的探针.

未来中国空间站巡天望远镜将释放小行星的高 精度观测资料, 因此研究与地面观测资料联合进行 高精度小行星历表改进的方法及相关应用将是下一 阶段的研究重点.

\section{参考文献}

1 Berthier J, Hestroffer D, Carry B, et al. Miriade: A service for solar sytem ojects ephemerides in the VO framework. Europ Planet Sci Cong, 2009. 676

2 Gwyn S D J, Hill N, Kavelaars J J. SSOS: A moving-object image search tool for asteroid precovery. Publ Astron Soc Pac, 2012, 124: 579-585

3 Bowell E, Wasserman L H, Muinonen K, et al. A search for the lost asteroid (719) Albert. Bull Am Astronom Soc, 1993, 25 : 1118 
4 Hu S C, Ji J H, Zhao Y H, et al. Determination and precision analysis of Tutatitis orbit during Chang'e-2 flyby asteroid experiment (in Chinese). Sci Sin-Tech, 2013, 43: 506-511 [胡寿村, 季江徽, 赵玉晖, 等. 嫦娥二号飞越小行星试验中图塔蒂斯轨道确定与精度分析. 中国科学: 技术 科学, 2013, 43: 506-511]

5 Chesley S R, Chodas P W. Asteroid close approaches: Analysis and potential impact detection. Asteroids III, 2002, 55: 69

6 Yuan Y, Fu Y N, Cheng Z. A prediction method for ground-based stellar occultations by ellipsoidal solar system bodies and its application. Res Astron Astrophys, 2017, 17: 45

7 Tang H J, Li F, Fu Y N. Application of close encounters in determining the masses of asteroids (in Chinese). Acta Astron Sin, 2017, 58: 101-108 [唐怀金, 李凡, 傅燕宁. 密近交会在确定小行星质量中的应用评估. 天文学报, 2017, 58: 101-108]

8 Ivantsov A V. Dynamical model of motion for asteroids based on the DE405 theory. Kinemat Phys Celest Bodies, 2007, 23: 65-69

9 Stoica P, Larsson E G, Li J. Adaptive filter-bank approach to restoration and spectral analysis of gapped data. Astron J, 2000, 120: 2163-2173

10 Bottke W F Jr., Vokrouhlický D, Rubincam D P, et al. The Yarkovsky and Yorp effects: Implications for asteroid dynamics. Annu Rev Earth Planet Sci, 2006, 34: 157-191

11 Wyatt S P, Whipple F L. The Poynting-Robertson effect on meteor orbits. Astrophys J, 1950, 111: 134-141

12 Bottke W F Jr., Vokrouhlick D, Rubincam D P, et al. The effect of Yarkovsky thermal forces on the dynamical evolution of asteroids and meteoroids. Asteroids III, 2002, 395: 408

13 Li F, Fu Y, Yuan Y. A new mass determination of (349)Dembowska with close encounters. Astrophys J, 2019, 157: 210

14 Giorgini J D. Status of the JPL horizons ephemeris system. IAU General Assembly, 2015. 22

15 Folkner W M, Williams J G, Boggs D H, et al. The planetary and lunar ephemerides DE430 and DE431. Interplanet Network Prog Rep, 2014, 196: $1-81$

16 Knezevic Z, Milani A. Asteroids dynamic site-AstDyS. IAU Joint Discus, 2012. 7

17 Farnocchia D, Chesley S R, Chamberlin A B, et al. Star catalog position and proper motion corrections in asteroid astrometry. Icarus, 2015, 245: 94-111

18 Shampine L F. Computer Solution of Ordinary Differential Equations. The Initial Value Problem. San Francisco: W. H. Freeman, 1975. $315: 316$

19 Hilton J L, Acton C, Arlot J E, et al. Report of the IAU Commission 4 Working Group on standardizing access to ephemerides and file format specification. arXiv: 1507.04291

20 Press W H, Teukolsky S A, Vetterling W T, et al. Numerical Recipes 3rd edition: The Art of Scientific Computing. Cambridge: Cambridge University Press, 2007. 807-809

21 Stokes G H, Evans J B, Viggh H E M, et al. Lincoln near-earth asteroid program (LINEAR). Icarus, 2000, 148: 21-28

22 Ofek E O. MATLAB package for astronomy and astrophysics. Astrophysics Source Code Library, 2014

23 Brown A G A, Vallenari A, Prusti T, et al. Gaia Data Release 2. Summary of the contents and survey properties. Astron Astrophys, 2018, 616: A1

24 Fienga A, Manche H, Laskar J, et al. INPOP new release: INPOP13b. arXiv: 1405.0484 


\title{
Ephemeris development for asteroids 35633 and 135356 and their orbital evolution induced by a close encounter
}

\author{
LI Fan ${ }^{1,2 *}$, YUAN Ye ${ }^{1,3} \&$ FU YanNing ${ }^{1,3}$ \\ ${ }^{1}$ Purple Mountain Observatory, Chinese Academy of Sciences, Nanjing 210033, China; \\ ${ }^{2}$ University of Chinese Academy of Sciences, Beijing 100049, China; \\ ${ }^{3}$ School of Astronomy and Space Science, University of Science and Technology of China, Hefei 230026, China
}

Based on the newly determined mass of (349)Dembowska, the ephemerides of two asteroids (35633 and 135356) were improved by taking into account the effects of their close encounter with (349)Dembowska. A Monte-Carlo method was used to determine the time-dependent uncertainty of the ephemerides. Reliability of the improvements were verified based on the observations from the Yaoan High Precision Telescope. The improved ephemerides were compared with those provided by Jet Propulsion Laboratory (JPL), for which the effects of close encounters were not considered. The results show that rapid and significant orbital evolution presents in a short time interval around the instant of the closest approach between the encountering bodies, which represents the effects of (349)Dembowska. Even though the effects will not be detectable by ground-based observations in a certain time, the extrapolation accuracy of ephemerides will decrease significantly without considering the effects when developing ephemerides.

ephemeris, asteroid, close encounter

PACS: $95.10 .-\mathrm{a}, 95.10 . \mathrm{Eg}, 95.10 . \mathrm{Km}, 95.10 . \mathrm{Jk}$

doi: 10.1360/SSPMA-2020-0080 